\title{
Review
}

\section{Opioid peptides and metabolic regulation}

\author{
D. Giugliano ${ }^{1}$, R. Torella ${ }^{1}$, P.J. Lefèbvre ${ }^{2}$ and F. D'Onofrio ${ }^{1}$ \\ ${ }^{1}$ Institute of General Medicine, Medical Therapy and Metabolic Disease, Faculty of Medicine I, University of Naples, Italy and \\ ${ }^{2}$ Division of Diabetes, Institute of Medicine, University of Liège, Belgium
}

The sap of the opium poppy has been recognised to have medical properties since the dawn of written history. Since the first "piqûre" experiment of Claude Bernard more than a century ago, morphine has been acknowledged to induce hyperglycaemia [1]. In the early 1970s, research was begun directed toward the demonstration of endogenous ligands for specific receptor occupancy, because a number of groups demonstrated that the analgesic action of morphine probably was a consequence of stereospecific interactions between opiates and receptors in the central nervous system [2-4]. Evidence for the existence of endogenous opiate-like compounds in the brain was provided by Terenius and Wahlström [5] and Hughes [6] and this created an enormous interest in the action of both exogenous and endogenous opiates. Physiological roles for these substances have been described in such diverse areas as nociception, behaviour and psychiatry, appetite, stress and shock [7]. Moreover, the demonstration that endogenous opioid peptides are widely distributed in sites involved in glucose homeostasis, including the central and peripheral divisions of the autonomic nervous system, the pancreas, the gut and the hypothalamopituitary tract $[8,9]$, has led to the suggestion that they may participate in the regulation of glucose homeostatis. This review is aimed at reviewing the current knowledge on the role of endogenous opioid peptides in metabolic regulation. We use the term opiate to refer to morphine-like alkaloids, and the term opioid to refer to endogenous peptides, reserving the term endorphin for $\beta$-endorphin and related peptides [10].

\section{Opioid peptides and receptors}

All opioids derive from one of three precursor peptides, whose structure has been elucidated from DNA analysis [11]. It is now clear that there are at least three genes producing large peptides whose fragments have opioid activity. These precursors are preproopiomelan- ocortin (POMC), preproenkephalin and preprodynorphin [12-14]. Each precursor is about the same length (265, 263 and 256 amino acid residues respectively). POMC is processed to a variety of peptides including ACTH, MSH, corticotropin-like intermediate lobe peptide (CLIP), beta lipotropin (LPH), $\gamma$-endorphin, $\beta$-endorphin and $\alpha$-endorphin. $\beta$-endorphin forms the C-terminus of POMC and has potent opioid activity [15]. Preproenkephalin (or proenkephalin A) contains one copy of Leu-enkephalin and six copies of the Metenkephalin sequence. Preprodynorphin (or proenkephalin B) is the source of the extended Leu-enkephalins $\alpha$ - and $\beta$-neoendorphin (decapeptides with the $\mathrm{N}$-terminal having the same sequence as Leu-enkephalin), dynorphin (a seventeen amino acid sequence of which one end has the same sequence of amino acids as Leu-enkephalin), rimorphin (dynorphin B, another Leu-enkephalin containing peptide) and leumorphin.

A lot of evidence indicates heterogeneity of opiate receptors [16-18]. Using different pharmacological approaches, it has been possible to postulate the existence of at least four types of opiate receptors. $\beta$-endorphin shows a great affinity for $\mu$-receptor, the original morphine receptor, although it is also active at $\delta$ - and $\varepsilon$-receptors. Enkephalins interact with the $\delta$-receptor, which, unlike the $\mu$-receptor, is resistant to naloxone. Prodynorphin-derived peptides interact with the $\kappa$-receptor which is also relatively resistant to naloxone.

\section{Opioid peptides and glucose metabolism}

\section{Central effects}

Parentheral administration of morphine given in a large dose produces hyperglycaemia in many animal species [19]. However, a similar rise in blood sugar can be obtained with a much smaller dose injected into a lateral cerebral ventricle. In fact, intraventricular injec- 
tion of morphine or $\beta$-endorphin leads to a rapid and sustained elevation of blood glucose in cats and rats $[20,21]$. Because this effect is reduced by section of the sympathetic ganglia or adrenal ablation, it has been suggested that morphine-induced hyperglycaemia is a centrally-innervated, sympathetically-mediated effect. The evidence for this is also based on the observation that intracisternal administration of synthetic human $\beta$-endorphin in conscious adult male rats increased plasma epinephrine concentrations, while adrenal denervation or intracisternal naloxone totally inhibited the catecholamine response to the opioid [22]. According to Feldberg et al. [23] the site of action of agents (morphine, $\beta$-endorphin, TRH, bombesin) which produce hyperglycaemia after intraventricular and intracisternal injection is the ventral surface of the brainstem: for all agents tested, bilateral adrenalectomy abolishes the hyperglycaemic response. Thus, glucose rise produced by these substances represents an increased central sympathetic outflow to the adrenal medulla and peripheral sympathetic nerve endings, leading to peripheral catecholamine release.

\section{Peripheral effects}

In vitro. Evidence has accumulated indicating that opiates and opioids may influence carbohydrate metabolism in a direct way. Matsumura et al. [24] found an increased glucose release in the medium when liver cells from fed rats were incubated in the presence of $\beta$-endorphin. This effect appeared to be dose-related, cAMP-dependent and consequent to increased glycogenolysis and neoglucogenesis from L-lactate. These findings were not confirmed by Brubaker et al. [25] who, evaluating the effects of physiological and supraphysiological concentrations of $\beta$-endorphin on isolated rat hepatocytes, were unable to show any influence of the opioid on both hepatic glucose production and glycogen phosphorilase $a$ activity. Differences in the method of cell preparation and maintenance might have been important to explain the divergent findings obtained in the aforementioned studies and in other reports of the literature [26, 27]. Met-enkephalin and Leu-enkephalin have also been reported to stimulate glucose production by rat hepatocytes, but only at very high concentrations [27]. As suggested by Brubaker et al. [25], the relevance of enkephalin-stimulated hepatic glucose production is at present unclear, since it has been reported to occur via a cAMP-independent mechanism and to be naloxone-resistant. $\beta$-endorphin has been shown to bind nonopiate receptors in rat liver which are coupled to adenylyl-cyclase; activation of these receptors results in increased intracellular levels of cAMP [28]. Since neither Met-enkephalin, Leuenkephalin nor naloxone effectively compete with $\beta$-endorphin for the peripheral binding sites [28], it is conceivable that the reported effects of enkephalins represent either a non-specific effect on rat hepatocytes or stimulation of subtypes of opiate receptors not linked to cAMP and resistant to naloxone.

In vivo. Radosevich et al. [29] have shown that lowdose infusion of $\beta$-endorphin $(0.2 \mathrm{mg} / \mathrm{h})$ in the conscious $\mathrm{dog}$, in which the endocrine pancreatic function was clamped at basal levels with somatostatin plus intraportal replacement of insulin and glucagon, caused a fall in plasma glucose concentrations owing to a $25 \%$ fall in tracer-determined glucose production, an effect observed in the absence of changes in circulating levels of insulin, glucagon, catecholamines and cortisol. The glucose-lowering effect of $\beta$-endorphin was thought to be the result of a direct action on the liver, since the observation of Houghten et al. [30] that $\beta$-endorphin does not cross the blood-brain barrier in a significant amount when given intravenously. This interpretation, however, has been recently questioned, because significant brain uptake of $\beta$-endorphin has been documented [31]; on the other hand, some amount of $\beta$-endorphin may also be taken up by the circumventricular organs which lack the blood-brain barrier [32]. Thus, the possibility that $\beta$-endorphin may influence glucose metabolism in dogs via a centrally-mediated effect cannot be excluded. On the other hand, a combined rise in adrenaline, glucagon and cortisol explains the increase in glucose production which follows high dose morphine infusion $(16 \mathrm{mg})$ in the $\operatorname{dog}$ [33].

Recent data by El-Tayeb et al. [34] in the conscious dog indicate that $\beta$-endorphin $\left(0.06 \mathrm{~g} \cdot \mathrm{kg}^{-1} \cdot \mathrm{min}^{-1}\right)$ modulates the effects of epinephrine on the liver, producing a relative inhibition of catecholamine-stimulated hepatic glucose production and a potentiation of epinephrine's inhibitory effect on overall glucose uptake. The authors suggested a possible role for opioids in modulating the glucoregulatory responses to stress. The suggestion that opioids may play a role in the redistribution of glucose that occurs during stress or exercise has been put forward by Werther et al. [35] who found that infusion of D-met ${ }^{2}-$ pro $^{5}$ enkephalinamide (DMPE), a potent opiate agonist, led to a small but consistent fall in plasma glucose in the dog related to a rise in glucose utilization independently of hormonal changes.

Concerning humans. Reid et al. [36] and later Feldman et al. [37] reported increased plasma glucose levels following a single intravenous bolus of $\beta$-endorphin in normal subjects. It could not be determined in these studies, however, whether the effects of the opioid were direct or mediated by the parallel changes in pancreatic hormone levels. Recently, Paolisso et al. [38] evaluated the influence of $\beta$-endorphin infused at low pharmacological dose $(0.5 \mathrm{mg} / \mathrm{h})$ on glucose homeostasis in normal subjects using the euglycaemic clamp technique in which the endocrine pancreatic function was fixed at its basal level with somatostatin together with replacement of basal insulin and glucagon by the exogenous infusion of the hormones. In this new metabolic condition (Fig. 1), $\beta$-endorphin failed to 

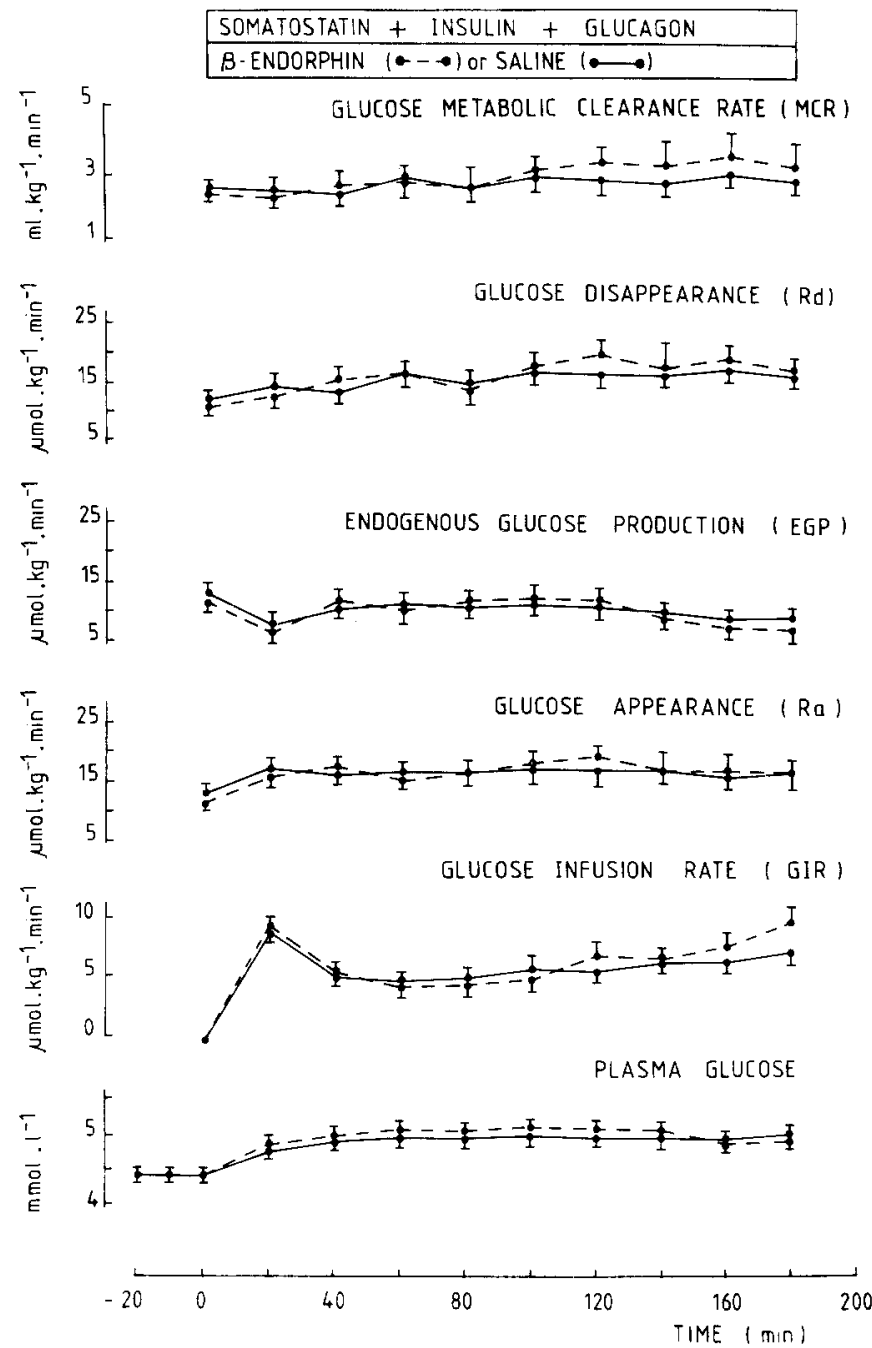

Fig. 1. Effects of human $\beta$-endorphin $(0.5 \mathrm{mg} / \mathrm{h}$ or $143 \mathrm{nmol} / \mathrm{h})$ infusion on glucose homeostasis in normal subjects. Pancreatic function was fixed at its basal rate by somatostatin and basal insulin and glucagon levels were replaced by exogenous infusions. In this condition, $\beta$-endorphin failed to modify any of the numerous parameters of glucose homeostasis. From Paolisso et al. [38]. With permission of the copyright holder

have significant influence on the various parameters of tracer-determined glucose metabolism (production, utilization, and clearance), nor was any difference found in the plasma concentrations of the counterregulatory hormones adrenaline, noradrenaline and cortisol. Moreover, the lack of effect of $\beta$-endorphin on the circulating levels of glycerol and alanine, two gluconeogenic precursors, makes unlikely a direct effect exerted by the opioid at the level of intermediate metabolism. Interestingly enough, this $\beta$-endorphin dose caused plasma glucose levels to rise when infused in humans in the absence of clamp [38]. All this seems to indicate that the metabolic effects of $\beta$-endorphin in normal man are a consequence of the changed hormonal "milieu" and not the expression of intrinsic metabolic properties of the opioid. Thus, $\beta$-endorphin-induced hyperglycaemia in normal subjects is secondary to its stimulation of pancreatic glucagon release (Fig.2).

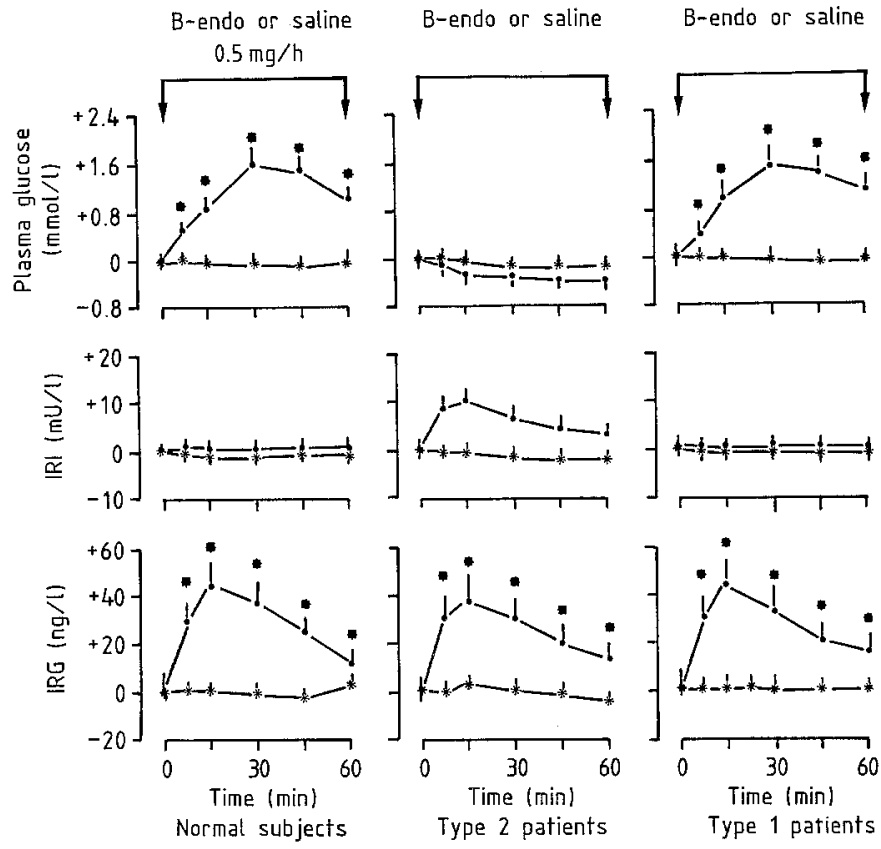

Fig. 2. Influence of human $\beta$-endorphin $(\Theta, 0.5 \mathrm{mg} / \mathrm{h})$ or saline $C_{*}$ ) infusion on the plasma concentration of glucose, immunoreactive insulin (IRI) and immunoreactive glucagon (IRG) in normal subjects, Type 2 (non-insulin-dependent) patients and Type 1 (insulin-dependent) diabetic patients. $\beta$-endorphin increased glucagon levels in all subjects, but stimulated insulin only in Type 2 diabetes. Glycaemia increased in both normal subjects and Type 1 patients, but decreased in Type 2 patients as a consequence of $\beta$-endorphininduced hormonal changes (original data)
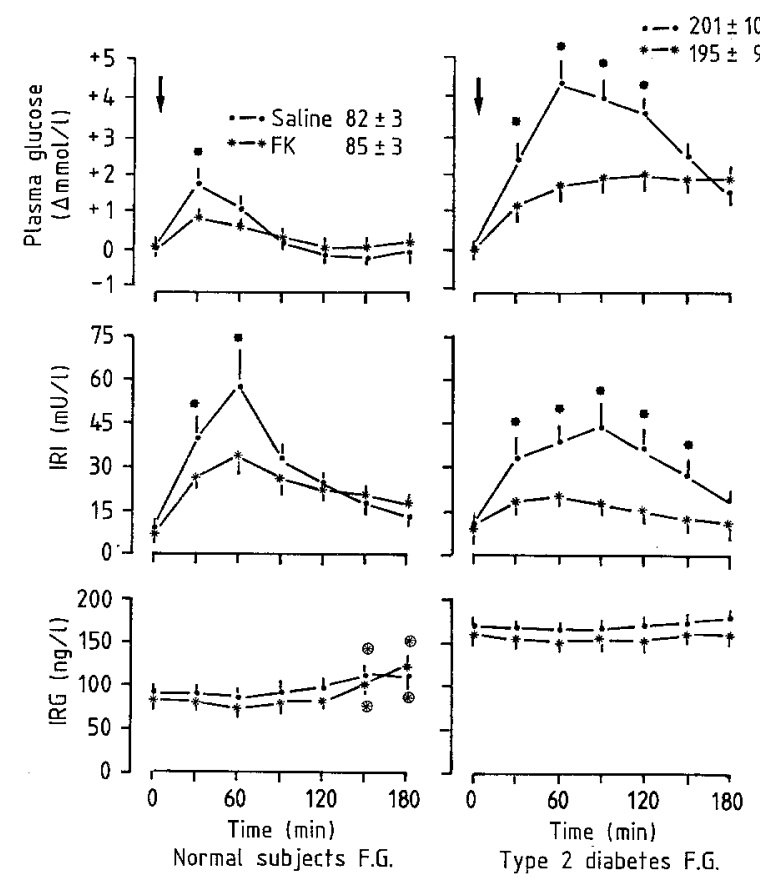

Fig. 3. Effects of the long-acting Met-enkephalin analogue DAMME (FK 33-824, Sandoz) upon the plasma glucose, insulin and glucagon responses to a standard breakfast test ( $500 \mathrm{Kcal})$ in normal subjects and in Type 2 patients. The analogue blunted the insulin response to the meal, having no effect on the glucagon response. The attenuated plasma glucose increase in the FK-treated groups probably was the consequence of reduced glucose absorption from the gut. F.G. = fasting glucose. From Giugliano et al. [40]. With permission of the copyright holder 
The Met-enkephalin analogue DAMME (D-Ala ${ }^{2}$, $\left.\mathrm{MePhe}^{4}, \mathrm{Met}(0) \mathrm{ol}\right)$ has been shown to cause a slight decrease of plasma glucose in normal subjects without major changes of insulin and glucagon [39]. Moreover, DAMME blunts the plasma glucose rise in response to oral glucose or standard meal [40] (Fig.3), although this effect appears to be related to the inhibitory action of the peptide on gastric motility and emptying [41].

To summarize, opioid peptides appear to influence glucose homeostasis in animals at different levels (central and peripheral). In normal subjects, the evidence for multiple sites of action is lacking, since the welldocumented hyperglycaemic effect of $\beta$-endorphin is secondary to its impact on pancreatic hormone secretion and not a consequence of a direct modulation of glucose metablism.

\section{Opiates, opioids and pancreatic islet function}

The demonstration of opioids in the pancreatic islets [42-44] has suggested the possibility that, besides the central effects, they may affect the endocrine pancreas by local or humoral pathways. The influence of the various opiates and opioids upon the endocrine pancreatic secretion has been extensively investigated using different experimental approaches.

\section{In vitro studies}

Ipp et al. [45] reported for the first time that both morphine and $\beta$-endorphin stimulated insulin and glucagon release and inhibited somatostatin from the perfused $\operatorname{dog}$ pancreas. The same effects have been demonstrated for morphine, Met-enkephalin and Leuenkephalin as far as insulin and somatostatin are concerned [46]. Curiously, the opiate antagonist naloxone also stimulated the release of canine insulin whereas the same concentrations did not affect glucagon release [45]. $\beta$-endorphin inhibited basal and glucosestimulated insulin release from pancreatic slices of rabbit [47]. Enkephalins seem to have a dose-dependent effect on insulin release from perifused pancreatic islets or isolated rat pancreas, low concentrations being stimulatory $[48,49]$ and high concentrations being inhibitory [48-51] or ineffective [49]. On the other hand, recent evidence demonstrates an inhibitory effect of proenkephalin A- and B-groups-derived peptides on insulin release from isolated perfused rat pancreas [ 52 , 53].

\section{In vivo studies}

Ipp et al. [54] showed in unstressed conscious dogs that morphine, at a dose approximately twice that used in clinical medicine, caused increases in circulating levels of insulin and glucagon without changing glucose. However, similar doses of morphine caused plasma glucose to rise more than $6.63 \mathrm{mmol} / 1$ in alloxan diabetic dogs as a consequence of opiate-induced glucagon release in the absence of accompanying insulin secretion [54]. Similar results have been obtained in the dog with the potent analogue DMPE [55]. In the rat, $\beta$ endorphin decreased plasma insulin levels and increased plasma glucagon and somatostatin concentrations [24]. In the goat both morphine and enkephalin caused a fall in plasma insulin levels [56]. In the rabbit $\beta$-endorphin inhibited basal insulin and the response to glucose, while potentiating arginine-stimulated glucagon release [57]. Despite the difficulty to reconcile the literature data, some general conclusions seem indicated:

1) The results of in vitro studies are at present inconclusive, since the effects of opiates and opioids on pancreatic islet function seem dependent on the agent investigated, dose administered, experimental procedure used and concentrations of glucose in the medium. The results of in vivo studies seem more univocal and suggest an inhibitory effect exerted by opioids on insulin release. In goats, rabbits and rats $\beta$-endorphin inhibits insulin release; while in dogs, morphine and enkephalins raise insulin plasma levels. This, however, might not be surprising in light of the evidence that canine $B$ cells respond to adrenaline increasing rather than decreasing insulin output, as happens in other animal species [58]. Thus, it is possible that the pancreatic islets of dogs have different types of opioid receptors or receptors with different affinity.

2) Almost all studies indicate that morphine and $\beta$ endorphin stimulate glucagon secretion $[59,60]$. Enkephalins seem to inhibit glucagon release in vitro [51], but the paucity of in vivo studies does not allow any conclusion to be drawn.

3) While a decreased somatostatin release might represent the mediator of the stimulatory effects of opiates and opioids in vitro $[45,46]$, the results of some in vivo studies do not support a major role for somatostatin as the mediator of the opioids effects on pancreatic hormone levels [61, 62].

4) The reported increase in plasma catecholamine concentrations during morphine administration in dogs [33] makes it likely that some metabolic effects of opiates may have a sympathetic mediation. However, other studies have failed to show any effect of morphine on plasma catecholamine levels [63] and neither $\beta$-endorphin nor enkephalins are known to influence the plasma concentrations of both adrenaline and noradrenaline.

\section{Human studies}

Reid et al. [36] made the first observation that a single i. v. bolus of $\beta$-endorphin $(2.5 \mathrm{mg}$ ) increased plasma insulin and glucagon levels in normal women. These findings were confirmed by Feldman et al. [37] who also showed that the dose-response curve for the effect 


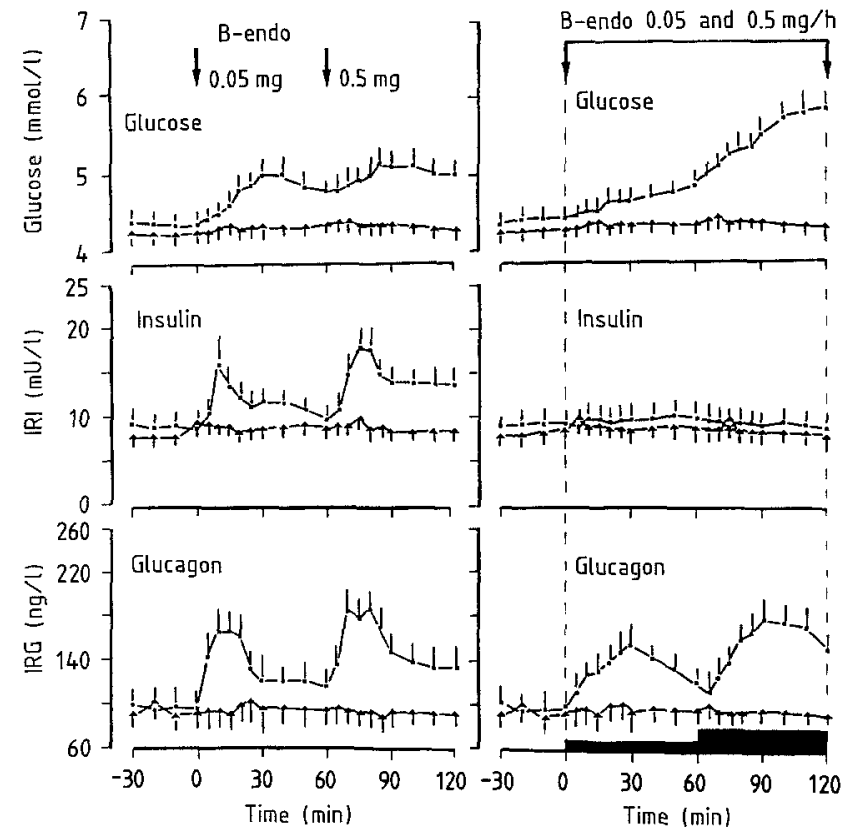

Fig.4. Effects of human i.v. bolus administration (left) or i.v. infusion $\beta$-endorphin upon the plasma concentration of glucose, insulin and glucagon in normal subjects. The consecutive i.v. boluses raised the plasma concentrations of glucose, insulin and glucagon, while the infusions increased plasma glucose and glucagon, but did not change insulin. This last finding suggests a relative inhibition of insulin release during the infusion of $\beta$-endorphin, which raises the plasma opioid concentrations to values well below those obtained with the i.v. bolus administration. From Giugliano et al. [64]. With permission of the copyright holder

of $\beta$-endorphin on insulin release was bell-shaped: the threshold dose that stimulated insulin was $5 \mu \mathrm{g}$, the maximal insulin response was seen after a $50 \mu \mathrm{g}$ bolus, while the highest dose tested $(2.5 \mathrm{mg})$ produced only small changes in plasma insulin. Since these two studies, $\beta$-endorphin was acknowledged to have a stimulatory effect on insulin and glucagon secretion in humans. Recent data, however, have confuted this current opinion. An unexpected finding observed during the infusion of human $\beta$-endorphin $(0.5 \mathrm{mg} / \mathrm{h})$ was the failure of plasma insulin to rise in response to the opioid or the accompanying hyperglycaemia (Fig. 2). It has been speculated [38] that the different kinetics of the opioid obtained with the two routes of $i$.v. administration could have been important, since the i.v. bolus produces very high plasma $\beta$-endorphin levels within a few minutes, while the $i$.v. infusion progressively increases peripheral opioid concentrations. To test this possibility, Giugliano et al. [64] studied the effect of either i.v. bolus or i.v. infusion of human $\beta$-endorphin in the same subjects, the total dose of opioid given in each experiment being constant (Fig. 4). With this approach, the authors were able to demonstrate a dual, dose-dependent effect of $\beta$-endorphin on insulin secretion in man. The i.v. bolus $(50 \mu \mathrm{g})$ of $\beta$-endorphin produced plasma levels of the opioid more than 200 -fold the basal values and raised insulin plasma levels, while the i.v. infusion $\left(50 \mu \mathrm{g} \cdot \mathrm{h}^{-1}\right)$ raised plasma $\beta$-endorphin concentrations 7-8-fold and inhibited insulin. Some studies have indicated that stress is associated with a 3-10-fold increase in plasma $\beta$-endorphin levels $[65,66]$ and relative suppression of insulin release is observed in stressful situations [67]. This may be mediated, at least in part, by endogenous opioid peptides. In support of this view, large doses $(8-16 \mathrm{mg})$ of the peripheral opioid agonist loperamide, which has poor penetration through the blood-brain barrier, suppresses insulin release while raising blood glucose [68]. Finally, $\beta$-endorphin inhibited nutrient (glucose and arginine)-induced insulin responses in normal subjects (Giugliano et al., unpublished observations).

The Met-enkephalin analogue DAMME had no effect on basal insulin and glucagon concentrations, but significantly inhibited the insulin response following an oral or intravenous glucose challenge $[40,69]$. This was accompanied by reduced glucose disappearance rates, indicating that the reduction of insulin was biologically significant. Moreover, the insulin response to the amino acid arginine or to the more physiologic breakfast test were also reduced by DAMME [40], pointing to a modulatory inhibiting role for enkephalin in the regulation of insulin release in humans. The failure of naloxone to alter either basal or glucose-stimulated insulin secretion in normal humans [70,71] seems not at variance with the view that opioids modulate negatively insulin release, since some hormonal effects of $\beta$-endorphin are resistant to naloxone [37] and since the opioid may also bind to nonopiate receptors [28]. As these receptors are coupled to adenyl-cyclase, their activation would result in increased intracellular levels of cAMP which would be expected to enhance insulin secretion. Thinking along this line, one could speculate that the ability of high dose $\beta$-endorphin to promote insulin release in humans would result from activation of non-opiate receptors in pancreatic islets.

Thus, $\beta$-endorphin stimulates glucagon secretion and has a dual, dose-dependent effect on insulin release in normal subjects; enkephalins, at least Met-enkephalin, do not seem to play a role in glucagon secretion; but Met-enkephalin inhibits stimulated insulin responses.

\section{Obesity}

\section{In animals}

Several experimental data indicate a role for opioids in food intake. Much of this evidence is based on the ability of the opiate antagonist naloxone to inhibit feeding in a variety of situations and species [72]. This effect of naloxone is directed at ingestive behaviours in general, since the drug also inhibits drinking [73]. Given the observation that naloxone and other antagonists decrease nutrient intake, it might be expected that pro- 
longed administration would lead to a loss of body weight. The issue has been addressed by studying the effect of chronic administration of naltrexone to genetically obese mice (ob/ob) and their lean littermates. The results of these studies [74] showed that chronic opioid antagonism did not modify the normal daily weight gain of normal weight rodents but slowed or prevented the development of obesity in genetically obese rodents. An interesting finding which emerged from the study of Recant et al. [74], as well as from other studies $[75,76]$, was the elevated levels of immunoreactivity $\beta$-endorphin in the plasma and/or pituitary of obese animals. These elevations, however, are not characteristic of all obese rats [77].

Various studies have documented the ability of both opiates and opioids to stimulate food intake. An injection of $\beta$-endorphin into the lateral ventricles stimulated feeding in sheep [78] and rats [79]; this effect was reversed by opiate antagonists. In general, opiates appear to stimulate preferentially the intake of foods with a higher energy requirement. Several lines of evidence support the hypothesis that increased production of $\beta$-endorphin or other opioids may lead to obesity: (1) the high levels of $\beta$-endorphin found in obese rodents; (2) the effects of opioids on ingestion; (3) the increased secretion of immunoreactive $\beta$-endorphin during periods of increased appetite [80]; and (4) the ability of naloxone to reduce the augmented insulin output from pancreatic islets of obese but not lean mice [74]. What is at present still unclear is whether the augmented opioid levels found in obese rodents are a cause or a consequence of obesity. Some authors [81] assayed for $\beta$-endorphin concentrations in the genetically obese mice across their development. They found that an increased posterior pituitary content of Leuenkephalin was evident even at one month of age, i.e. before the development of obesity; on the other hand, obesity came before the higher levels of $\beta$-endorphin. This question is still open.

\section{In humans}

Thinking along the lines outlined above, a neuroendocrine pathogenesis for obesity has been proposed and evidence for the involvement of neuropeptides has been claimed [82]. Concerning humans, is the evidence that relates the altered opioid system to weight gain so numerous as in animals? The first report by Givens et al. [83] that obese women presented elevated plasma levels of $\beta$-endorphin which correlated with increasing body weight, has been confirmed by other studies [84, 85]. Although it is a common opinion that the pituitary represents the main source of circulating plasma $\beta$-endorphin, the findings that $\beta$-endorphin lacks its circadian rhythm in obese children [85] and that the augmented opioid levels are dexamethasone-resistant [86] speak in favour of other sources of POMC-derived peptides in obese subjects. This alternative or addi- tional source may be the gastrointestinal tract. A standard meal, duodenal acidification and tetragastrin are challenges that normally release $\beta$-endorphin in the circulation [87]. Getto et al. [88] reported that ingestion of glucose produced an increase of plasma $\beta$-endorphin both in normal and obese subjects, although the response of the obese subjects was delayed or even greater [89]. Since there is no $\beta$-endorphin response to i.v. glucose challenge in obesity (Giugliano et al., unpublished observations), it seems reasonable to assume that the elevated $\beta$-endorphin concentrations of obese subjects come, at least to a great extent, from the gut.

Naloxone has been shown to reduce food intake in obese subjects [90], patients with Prader-Willi syndrome [91] or traumatic hypothalamic hyperphagia [78], and in normal subjects in whom feeding was induced by 2-deoxyglucose infusion [92]. Sternbach et al. [93] found that naltrexone administration to opiate addicts in the attempt to control relapse to using opiates was associated with a loss of appetite and marked body weight loss in some individuals. Although this evidence leaves little doubt that opioid antagonism influences eating habits in obese subjects and opiate addicts, the mechanism by which opioids increase food intake still remains a matter of debate.

As obese subjects have increased insulin levels and increased food intake, which might be due to increased endogenous opioid peptides, the possibility that the link between opioids and obesity could be through alterations in insulin secretion will be examined. Vettor et al. [94] studied the effect of a sustained infusion of naloxone $(4 \mathrm{mg}$ i.v. bolus plus $0.066 \mathrm{mg} / \mathrm{min}$ for $120 \mathrm{~min}$ ) upon glucose-induced insulin secretion in human obesity. They found that naloxone decreased the exaggerated insulin response to oral glucose in obese but not in thin subjects. Giugliano et al. [95] confirmed and extended these findings showing that a 10-day treatment with naloxone (1.2 $\mathrm{mg}$ twice a day, intramuscularly) significantly decreased the insulin and C-peptide responses to an oral glucose challenge $(75 \mathrm{~g})$ in obese but not in lean subjects. The evaluation of circulating C-peptide levels rules out the possibility that naloxone might have caused alterations of insulin clearance. Naloxone has also been shown to reduce the plasma insulin response to oral glucose in women with polycystic ovary syndrome and acanthosis nigricans [96], although the finding may be reconduced to the massive obesity of the patients investigated. Interestingly enough, in all studies plasma glucose tolerance curves did not change despite the marked reduction of stimulated insulin release, which suggests an improvement of tissue sensitivity to insulin probably mediated via a reduced down regulation of insulin receptors. The alternative possibility that naloxone might have dampened an increased responsiveness to the glucoseregulatory effects of opioids remains to be considered. In fact, unlike people of normal body weight, the infusion of human $\beta$-endorphin $(0.5 \mathrm{mg} / \mathrm{h})$ to obese sub- 


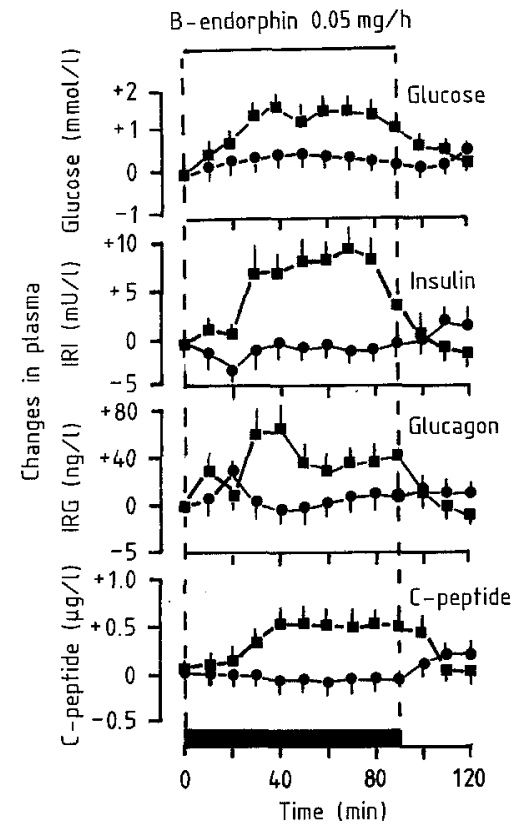

Fig.5. Effects of human $\beta$-endorphin i.v. infusion on the plasma concentration of glucose, insulin, glucagon and C-peptide in normalweight (filled circles) or obese (filled squares) subjects. Only in obese subjects did the opioid produce significant and long-lasting increases in the plasma levels of all parameters investigated; in lean people, $\beta$-endorphin did not change the plasma concentrations of glucose, insulin and C-peptide, but stimulated transiently glucagon. From Giugliano et al. [95]. With permission of the copyright holder

jects produces an immediate peak insulin response, suggesting an increased sensitivity of the pancreatic B cells to $\beta$-endorphin [97]. Obviously, this represents a pharmacological effect, since the plasma $\beta$-endorphin concentrations achieved with the $0.5 \mathrm{mg}$ dose were $30-40$-fold the basal levels. On the other hand, the infusion of a 10 -fold lesser dose $(0.05 \mathrm{mg} / \mathrm{h})$, which raises the plasma $\beta$-endorphin concentrations on the order of $200-300 \mathrm{fmol} / \mathrm{ml}$ (i. e. about $7-10$ fold the basal levels), increased the basal concentrations of plasma glucose, insulin, C-peptide and glucagon in obese but not in normal weight subjects [95] (Fig. 5).

To summarize, human obesity is characterised by: (1) increased plasma levels of $\beta$-endorphin; (2) increased responsiveness to its metabolic and hormonal effects; and (3) increased responsiveness of the pancreatic $B$ cells to naloxone. These features found in obese subjects may promote the occurrence of a vicious cycle in which the opioid stimulates insulin and glucagon release with resultant hyperglycaemia, which in turn amplifies the B-cell response. We must not forget, however, that many, although not all, endocrine abnormalities of human obesity may be secondary to the abnormal nutritional status of the patient [98], so that the findings reported could be the consequence rather than the cause of obesity. This issue is an important one since its resolution will have important physiological and possibly therapeutic implications.

\section{Diabetes}

The first suggestion that opioids might be involved in human diabetes came from the work of Leslie et al. [99] who observed that a proportion of patients with Type 2 (non-insulin dependent) diabetes mellitus who have taken the sulfonylurea chlorpropamide exhibited profound facial flushing when they drank alcohol (CPAF). Further reports [100, 101] suggested that CPAF was dominantly inherited, tended to aggregate in familial Type 2 diabetes, was common among Type 2 diabetic patients although it was also found among Type 1 (insulin-dependent) diabetic patients and non-diabetic subjects, and was associated with a relative freedom from vascular diabetic complications. Although this tendency to flush may be reproduced in susceptible individuals by the infusion of DAMME [99], a rise in circulating Met-enkephalin is unlikely to mediate CPAF since ethanol-induced CPAF does not lead to a rise in plasma Met-enkephalin concentrations [102]. An increased sensitivity to enkephalin has been proposed to explain the higher prevalence of CPAF among Type 2 diabetic patients.

In an attempt to obtain more direct information concerning the possible involvement of opioids in diabetes, Greenberg et al. [103] examined tissue concentrations of Met-enkephalin and $\beta$-endorphin of obese diabetic mice $(\mathrm{db} / \mathrm{db})$ and their lean littermates. They reported significant elevations of both $\beta$-endorphin and Met-enkephalin in extracts of pituitary, but not pancreas, adrenal or hypothalamus. Studying the concentration and processing of opioids in the pancreas and pituitary in $\mathrm{db} / \mathrm{db}$ mice during development of the diabetic syndrome, Timmers et al. [104] confirmed the results of Greenberg and extended them, demonstrating elevations in pancreatic $\beta$-endorphin and pituitary Leu-enkephalin. These alterations, however, seemed apparently related to obesity and hyperphagia or to hypercorticism, because they also occurred in obese (ob/ob) mice which were not grossly hyperglycaemic and had elevated rather than depleted pancreatic insulin content. The significant negative correlation between pancreatic free Met-enkephalin content (increased) and plasma insulin levels (decreased) suggested a functional relationship with insulin secretion. The observation that pituitary and hypothalamic levels of $\beta$-endorphin are diminished in female rats made diabetic by a single injection of streptozotocin, suggests that diabetes influences $\beta$-endorphin concentration in the hypothalamus-hypophyseal unit [105]. Clearly, this is a secondary event in diabetes probably related to reduced protein synthesis and may be a confounding factor in the evaluation of results from genetic models of diabetes in rodents.

Since the first report by Awoke et al. [106] of elevations in plasma $\beta$-endorphin in insulin-treated diabetic patients and plasma enkephalin-like activity in chlorpropamide-treated diabetic patients, a few studies have 


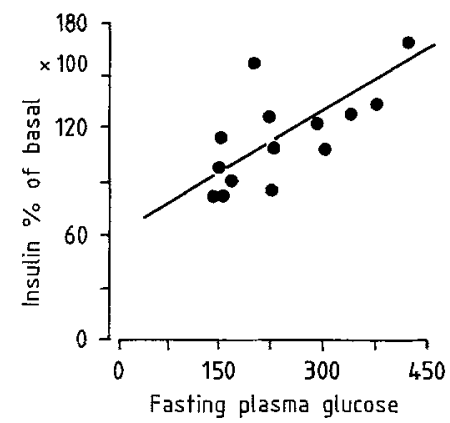

Fig.6. Correlation between fasting plasma glucose concentration and the insulin response (expressed as the integrated area above fasting, percentage of the basal values) to human $\beta$-endorphin infusion $(0.5 \mathrm{mg} / \mathrm{h})$ in Type 2 diabetic patients. $\mathrm{r}=0.61 ; p<0.01$. From Giugliano et al. [97] with permission of the copyright holder
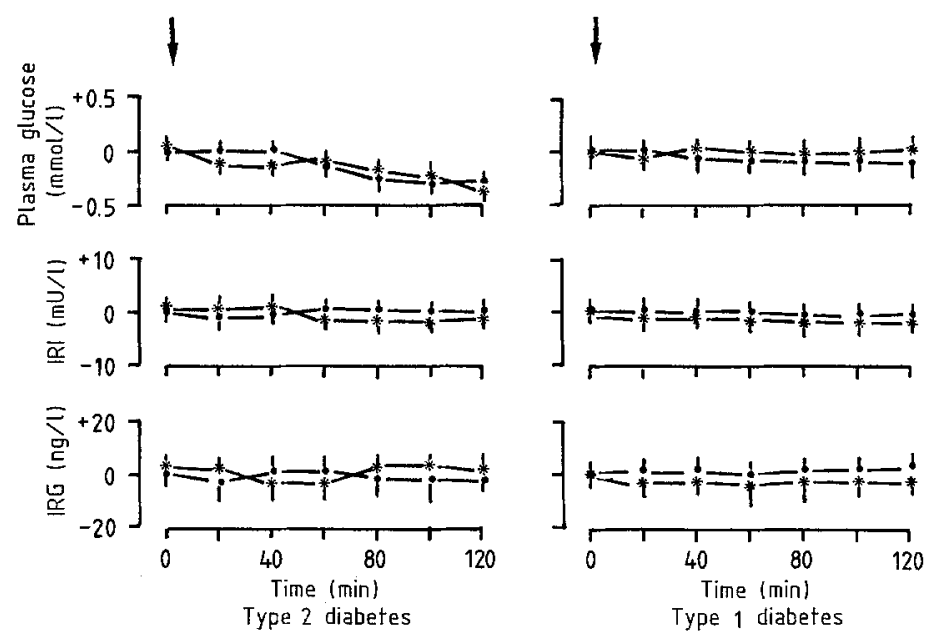

Fig. 7. Effects of long-acting Met-enkephalin analogue DAMME (FK 33-824, Sandoz, - - ) or saline ( $*$ - $*$ ) infusion upon the plasma concentration of glucose, insulin and glucagon in patients with Type 2 and Type 1 diabetes mellitus. No significant change was observed during the opioid infusion in both groups of patients (original data)

focussed on this topic with discordant results. Increased plasma levels of immunoreactive $\beta$-endorphin were found by Vermes et al. [107] in Type 2 patients, but not in Type 1 patients, and a positive correlation between the degree of retinopathy and the blood levels of $\beta$-endorphin emerged from the study. The findings were not confirmed by Buzzin et al. [108] who did not observe any significant difference in the plasma $\beta$-endorphin concentrations between Type 2 patients with background or proliferative retinopathy and normal subjects; the authors also failed to demonstrate any correlation between the degree of retinopathy and plasma $\beta$-endorphin. Solerte et al. [109] reported that Type 2 patients have lower plasma levels of $\beta$-endorphin than the non-diabetic population, probably related to a central inhibition of opioid production; although a reduced peripheral production was not excluded. Whatever the significance of changes in opioid plasma levels found in human diabetes, one could speculate that the divergent findings reported are an expression of the heterogeneity of the disease: in this regard, they may reflect either different pathogenetic events or different stages during development of diabetes.

Besides the alterations in plasma opioid concentration, recent evidence indicates that Type 2 diabetes is associated with altered glucometabolic responses to exogenous opioid administration. After the preliminary observation of Reid et al. [110] that $\beta$-endorphin may have a glucose-lowering effect in Type 2 patients resulting from a higher stimulation of insulin with respect to glucagon, other studies have examined in detail this topic. Giugliano et al. [97] found that an i.v. infusion of human $\beta$-endorphin $(0.5 \mathrm{mg} / \mathrm{h})$ in Type 2 patients resulted in progressive and simultaneous increments of plasma insulin and glucagon and decreased plasma glucose levels (Fig.2). Furthermore, $\beta$-endorphin unequivocally restored a clear-cut insulin response to i.v. glucose $(0.33 \mathrm{~g} / \mathrm{kg})$, while second phase insulin release was increased and glucose disposal accelerated [111]. Since a similar dose of $\beta$-endorphin inhibits rather than stimulates insulin secretion in the nondiabetic population [97], the authors hypothesised that the prevailing plasma glucose level played an important role in this context. In support of this view, a significantly positive correlation between the fasting plasma glucose concentration and the integrated insulin response to the opioid was found (Fig.6). Moreover, the reduction of fasting hyperglycaemia in diabetic patients by low dose insulin infusion blunted the insulin response to $\beta$-endorphin [112]. On the other hand, normal subjects made hyperglycaemic by glucose infusion responded to $\beta$-endorphin infusion with an elevation in plasma insulin levels [113]. Thus, hyperglycaemia alters the $\mathrm{B}$ cell sensitivity to $\beta$-endorphin which acts as a potentiator of insulin release in relation to the prevailing plasma glucose concentration. This may not be surprising since changes in circulating glucose levels modulate the response to opiate antagonism of feeding in animals [114]. Glucose may modify functionally the opiate receptor in a rapid manner, since $1 \mathrm{~h}$ of induced-hyperglycaemia in normal subjects can shift the normal response (insulin inhibition) to a diabetic response (insulin stimulation).

Met-enkephalin has been recently shown to have major effects on insulin secretion in Type 2 diabetes. In particular, DAMME inhibits insulin secretion induced by various secretagogues, as glucose, arginine and a standard meal [40], while having no evident effect on the basal insulin concentration (Fig. 3, Fig. 7). The finding that the inhibiting effect of DAMME on stimulated insulin secretion is amplified in Type 2 patients as compared to the non-diabetic population suggests an increased sensitivity of the diabetic B cell to enkephalins. This seems also in line with the report that naloxone increased insulin responses and glucose disappearance rates after an i.v. glucose challenge in Type 2 patients [70]. 
In a more general sense, an increased sensitivity of the diabetic B cells to the inhibitory effect of several endogenous, pancreatically-produced substances (Metenkephalin, catecholamines, prostaglandin E) has been hypothesized [115]. This evidence is based on the ability of pharmacological agents (naloxone, phentolamine, sodium salicylate), known to antagonize the effects of the aforementioned substances, to partially restore insulin secretion in Type 2 diabetes and to act synergystically when infused together. The importance of an altered "milieu interieur" in the pathogenesis of impaired insulin secretion in Type 2 diabetes is also suggested by the study of Verlohren and Jahr [116] who found that islets isolated during laparatomy from patients with Type 2 diabetes had normal insulin content, proinsulin biosynthesis and glucose-induced insulin secretion when tested in vitro.

With respect to the glucometabolic effects of exogenous $\beta$-endorphin administration, patients with Type 1 diabetes behave as normal subjects. In these patients, the opioid elicits a rise in plasma glucose levels which is glucagon-mediated (Fig. 2). On the other hand, DAMME has no apparent effect on the basal plasma levels of glucose, insulin and glucagon (Fig. 7).

\section{Heroin addiction}

Heroin users represent a useful model for studying the glucometabolic effect of chronic receptor occupancy. Heroin addicts have, with respect to control subjects, significantly higher fasting concentrations of insulin, glucagon and growth hormone, but present impaired tolerance to oral glucose [117]. While this finding seems mainly related to the marked reduction of stimulated insulin secretion, decreased glucose disposal mediated via a reduction of glucose-induced glucagon suppression cannot be excluded as a contributory factor. Since the same addicts respond appropriately to non-glucose signals, such as the amino acid arginine [117], a specific impairment of glucose-induced insulin secretion seems operative in these subjects rather than a nonspecific damping of insulin secretion. The fact that heroin addicts also have a markedly reduced insulin response to an i.v. glucose challenge with low values of glucose disappearance rates $\left(\mathrm{K}_{\mathrm{G}}<1.2\right)$, makes unlikely the possibility that a slow rate of gastric emptying of ingested glucose plays a major role in the diminished insulin response to oral sugar [118]. On the basis of this evidence, Giugliano et al. [119] put forward the hypothesis that heroin users have a metabolic situation similar to that found in Type 2 diabetic patients. This form of human diabetes is characterized by absent acute insulin response to glucose, the response to other secretagogues (arginine, isoproterenol, glucagon) being indistinguishable, in condition of fasting hyperglycaemia, to that of non-diabetic subjects [120]. The similarities between addicts and Type 2 patients are also supported by the reports of increased concentrations of glycated haemoglobin $A_{1}$ [121] and proteins [122] in addicts. Additional studies in addicts have demonstrated many changes in common with Type 2 patients, including increased fibrinogen levels [123], polycythaemia and increased reticulocyte count [124] and decreased HDL and apolipoprotein A levels [125]. Moreover, decreased antithrombin III biological activity in the presence of its normal plasma concentration has been reported to occur both in addicts [126] and in Type 2 patients [127] probably as a consequence of increased non-enzymatic glycation. Finally, as happens in Type 2 patients, sodium salicylate can restore to normal the depressed insulin response to i.v. glucose in addicts, suggesting that a prostaglandin-mediated defect in glucose recognition may play a role in the defective insulin secretion of heroin users [128].

\section{Conclusions}

The explosion of knowledge that followed the first identification of endogenous opioid peptides makes it somewhat difficult to integrate in a single theory the various and often contrasting data. However, it now seems evident that, at least in human beings, sufficient data exist to put forward a hypothesis as to their role in physiology and pathophysiology. Both $\beta$-endorphin and enkephalins are found in sites involved in the response to stress (pituitary, adrenals, endocrine pancreas) and their plasma concentrations, at least for $\beta$-endorphin, are known to increase during stress. $\beta$ endorphin and Met-enkephalin inhibit insulin secretion in a variety of metabolic situations and may help to depress B cells and to redirect glucose from insulindependent to non-insulin-dependent tissues during periods of glucose need (i.e. stress). This interpretation is also supported by the finding that $\beta$-endorphin stimulates glucagon secretion over a wide range of plasma concentrations, suggesting an important role for the opioid in the mediation of stress-induced glucagon release. Early studies showing stimulation of glucagon secretion in man by high physiological epinephrine doses have been recently disputed $[129,130]$. Moreover, the failure of $\beta$-endorphin to influence in a direct way glucose metabolism suggests that the opioid, unlike catecholamines, participates in the metabolic responses to stress through alterations in hormone secretion only. Finally, there is also evidence in humans that a synergistic interaction exists between neuro-modulators to dampen B cell secretory activity. Thus, epinephrine, $\mathrm{PGE}_{2}$ and Met-enkephalin, given at a dose which per se does not have an apparent effect on insulin release, causes a significant inhibition of insulin responses to glucose when given in combination [131]. On the other hand, $\beta$-endorphin may also play a positive role in the local (paracrine?) control of insulin release since the opioid is synthesised within the islet 
cells and the resultant concentrations are probably high enough to stimulate the $B$ cells.

As pointed out by Reid [72], obesity in Western societes has been attributed to the easy availability of a variety of palatable foods, decreased energy expenditure and the high stress of modern living. Since stress increases levels of opioids which have been implicated in palatability, perhaps the weight gain of people in Western societes is related to the activity of the opioid system. Evidence has been presented in this review indicating that the link between opioids and obesity may be through alterations in insulin secretion, since an increased sensitivity of the pancreatic B cells to $\beta$-endorphin has been demonstrated in obese subjects. Thus, in susceptible persons, the raised $\beta$-endorphin concentrations, secondary to a chronic stress state or to another unidentified cause, may induce hyperinsulinaemia, recently suggested to be the driving force for the occurrence of both insulin resistance and obesity [132]. Recent data by Giugliano et al. (unpublished observations) indicate that obese subjects are more prone than lean people to develop profound hyperglycaemia in response to physiological elevations of plasma $\beta$-endorphin and epinephrine.

A lot of evidence indicates that extrapancreatic factors are implicated in some pathogenetic aspects of Type 2 diabetes [133]. An increased sensitivity to the inhibiting effect of $\mathrm{PGE}_{2}$, catecholamines and enkephalins has been demonstrated as having a role in the pathogenesis of defective insulin secretion in human Type 2 diabetes [115]. As originally suggested by Giugliano et al. [119] a reduced $\beta$-endorphin tone in Type 2 diabetes might also be important in the pathogenesis of impaired insulin secretion. Taken together, the data seem to indicate that a profound alteration of the opioid system is present in human diabetes, although it is still unclear whether it represents a primitive event in the disease or is secondary to the diabetic state.

\section{References}

1. Bernard C (1877) Lecons sur le Diabète. J-B Bailière, Paris

2. Li CH (1964) Lipotropin, a new active peptide from pituitary gland. Nature 201: 924

3. Pert CB, Snyder SH (1973) Opiate receptor: demonstration in nervous tissue. Science 179: 1011-1014

4. Wong DT, Horng JS (1973) Stereospecific interaction of opiate narcotics in binding of ${ }^{3} \mathrm{H}$-dihydromorphine to membrane of rat brain. Life Sci 13: 1543-1556

5. Terenius L, Wahlström A (1975) Search for an endogenous ligand for the opiate receptor. Acta Physiol Scand 94: 74-81

6. Hughes $J$ (1975) Isolation of an endogenous compound from the brain with pharmacological properties similar to morphine. Brain Res 88: 295-308

7. Akil H, Watson ST, Young E, Lewis M, Khachatarieu J, Walker JM (1984) Endogenous opioids: biology and function. Annu Rev Neurosci 7: 233-255

8. Krieger DT, Liotta AS, Brownstein MJ, Zimmerman EA (1980) ACTH, $\beta$-lipoprotein and related peptides in brain, pituitary and bloos. Acta Endocrinol (Copenh) 104: 85-90
9. Krieger DT (1983) Brain peptides: what, where and why? Science 222: $975-985$

10. Hughes J, Kosterlitz HW (1983) Opioid peptides: introduction. Br Med Bull 39: 1-13

11. Rossier J (1982) Opioid peptides have found their roots. Nature 298: 221-222

12. Noda M, Furutani $Y$, Takahashi $H$, Tiyusato $M$, Hirose $T$, Inayama S, Nakanishi S, Numa S (1982) Cloning and sequence analysis of cDNA for bovine adrenal preproenkephalin. Nature 295: 202-206

13. Noda $M$, Teranishi $Y$, Takahashi $H$, furutani $Y$, Hirose $T$, Inayama S, Nakanishi S, Numa S (1982) Isolation and structural organization of the human preproenkephalin gene. Nature 297: 431-434

14. Kadikani H, Furutani $Y$, Takahashi $H$, Noda M, Morimoto $Y$, Hirose T, Asai M, Inayama S, Nakanishi S, Numa S (1982) Cloning and sequence analysis of cDNA for porcine B-neoendorphin-dynorphin precursor. Nature 298: 245-249

15. Jacqet YF, Marks N (1976) The c-fragment of beta-lipotropin: an endogenous neuroleptic or antipsychotogen? Science 194: 632-635

16. Lord JAH, Waterfield AA, Hughes J, Kosterlitz HW (1977) Endogenous opioid peptides-Multiple agonists and receptors. Nature 267: 495-499

17. Wuster M, Schulz R, Herz A (1981) Multiple opiate receptors in peripheral tissue preparations. Biochem Pharmacol 30: 1883-1887

18. Chang KJ, Cuatrecasas $P$ (1981) Heterogeneity and properties of opiate receptors. Fed Proc 40: 2729-2734

19. Feldberg W, Gupta KP (1974) Morphine hyperglycaemia. J Physiol (Lond) 238: 487-502

20. Borison HL, Fishburn BR, Bhide NK, McCarthy LE (1962) Morphine-induced hyperglycaemia in the cat. J Pharmacol Exp Ther 138: 229-235

21. Feldberg W, Shaligram SV (1972) The hyperglycaemic effect of morphine. Br J Pharmacol 46: 602-618

22. Van Loon GR, Appel NM, Ho D (1981) $\beta$-endorphin-induced stimulation of central sympathetic outflow: $\beta$-endorphin increase plasma concentrations of epinephrine, norepinephrine, and dopamine in rats. Endocrinology 109: 4653

23. Feldberg W, Pyke DA, Stubbs WA (1985) On the origin of noninsulin-dependent diabetes. Lancet I: 1263-1264

24. Matsumura M, Fukushima T, Saito $H$, Saito $S$ (1984) In vivo and in vitro effects of $\beta$-endorphin on glucose metabolism in the rat. Horm Metabol Res 16: 27-31

25. Brubaker PL, Sun A, Vranic M (1987) Lack of effect of $\beta$-endorphin on basal and glucagon-stimulated hepatic glucose production in vitro. Metabolism 36: 432-437

26. Allan EH, Green IC, Titheradge MA (1983) The stimulation of glygogenolysis and neoglucogenesis in isolated hepatocytes by opiate peptides. Biochem J 216: 507-510

27. Leach RP, Allan EH, Titheradge MA (1985) The stimulation of glycogenolysis in isolated hepatocytes by opioid peptides. Biochem J 227: 191-197

28. Dave JR, Rubinstein N, Eskay RL (1985) Evidence that $\beta$-endorphin binds to specific receptors in rat peripheral tissues and stimulates the adenylate cyclase-adenosine $3^{\prime}, 5^{\prime}$-monophosphate system. Endocrinology 117: 1389-1396

29. Radosevich PM, Williams PE, McRae JR, Lacy WW, Orth DN, Abumrad NN (1984) $\beta$-endorphin inhibits glucose production in the conscious dog. J Clin Invest 73: 1237-1241

30. Houghten RA, Swann RW, Li CH (1980) $\beta$-endorphin: stability, clearance behaviour, and entry into the central nervous system after intravenous injection of the tritiated peptide in rats and rabbits. Proc Natl Acad Sci USA 77: 4588-4591

31. Rapoport SI, Klee WA, Pettigrew KD, et al. (1980) Entry of opioid peptides into the central nervous system. Science 207: 84-86

32. Pardridge WM (1981) Transport of nutrients and hormones through the blood-brain barrier. Diabetologia 20:246-254

33. Radosevich PM, Williams PE, Brooks Lacy D, McRae JR, 
Steiner KE, Cherrington AD, Lacy WW, Abumrad NN (1984) Effects of morphine on glucose homeostasis in the conscious dog. J Clin Invest 74: 1473-2480

34. El-Tayeb KMA, Brubaker PL, Vranic M, Lickley HLA (1985) Beta-endorphin modulation of the glucoregulatory effects of repeated epinephrine infusion in normal dogs. Diabetes 34: 1293-1300

35. Werther GA, Joffe S, Artal R, Sperling MA (1985) Opiate modulation of glucose turnover in dogs. Metabolism 34: 136-140

36. Reid RL, Sandler JA, Yen SSC (1981) $\beta$-endorphin stimulates the secretion and glucagon in humans. J Clin Endocrinol Metab 52: 592-594

37. Feldman M, Kiser RS, Unger RH, Li CH (1983) Beta-endorphin and the endocrine pancreas. Studies in healthy and diabetic human beings. N Engl J Med 308: 349-353

38. Paolisso G, Giugliano D, Scheen AJ, Franchimont P, D'Onofrio F, Lefebvre PJ (1987) Primary role of glucagon release in the effect of $\beta$-endorphin on glucose homeostasis in normal man. Acta Endocrinol (Copenh) 115: 161-169

39. Stubbs WA, Jones A, Edwards CRW, Delitala G, Jeffcoate WJ, Ratter GM, Bloom SR, Alberti KGMM (1978) Hormonal and metabolic responses to an enkephalin analogue in normal man. Lancet II: $1225-1226$

40. Giugliano D, Quatraro A, Consoli G, Ceriello A, Torella R, D'Onofrio F (1987) Inhibitory effect of enkephalin on insulin secretion in healthy subjects and in non-insulin-dependent diabetic subjects. Metabolism 36: 286-289

41. Konturek SJ, Tasler J, Cieszkoski M, Jaworek J, Coy DH, Schally AV (1978) Inhibition of pancreatic secretion by enkephalin and morphine in dogs. Gastroenterology 74: 851-855

42. Bruni JF, Watkins WB, Yen SSC (1979) $\beta$-endorphin in the human pancreas. J Clin Endocrinol Metab 49: 649-651

43. Grube D, Voight KH, Weber E (1978) Pancreatic glucagon cells contain endorphin-like immunoreactivity. Histochemistry 59: $75-79$

44. Polak JM, Bloom SR, Sullivan SN, Facer P (1977) Enkephalinlike immunoreactivity in the human gastrointestinal tract. Lancet I: $972-974$

45. Ipp E, Dobbs R, Unger RH (1978) Morphine and $\beta$-endorphin influence the secretion of the endocrine pancreas. Nature (Lond) 276: 190-191

46. Hermansen K (1983) Enkephalins and the secretion of pancreatic somatostatin and insulin in the dog: studies in vitro. Endocrinology 113: 1149-1154

47. Rudman D, Berry CJ, Riedeburg CH, Hollins BM, Kutner MK, Dynn MJ, Chawla RK (1983) Effects of opioid peptides and opiate alkaloids on insulin secretion in the rabbit. Endocrinology $112: 1702-1710$

48. Green IC, Perrin D, Pedley KC, Leslie RDG, Pyke DA (1980) Effects of enkephalins and morphine on insulin secretion from isolated rat islets. Diabetologia 19: 158-161

49. Sachse G, Laube H, Svedberg J, Breidenbach T, Teschemacher H (1981) Opiates influence endocrine pancreatic secretion. Diabetologia 21: 322 (Abstract)

50. Ryder S, Gollapudi GM, Ryder D (1980) Morphine sulphate inhibits insulin release from isolated superinfused rat pancreas. Horm Metabol Res 12: 412-413

51. Kanter RA, Ensinck JW, Fujimoto WY (1980) Disparate effects of enkephalin and morphine upon insulin and glucagon secretion by islet cell cultures. Diabetes $29: 84-86$

52. Toyota T, Ishizuka J, Nagaoka J, Goto Y (1985) Effects of metenkephalin and dynorphin (1-17) on the secretion of insulin and glucagon from the isolated perfused pancreas. In: Sakamoto $\mathrm{N}$, Min HK, Baba $\mathrm{S}$ (eds) Current topics in clinical and experimental aspects of diabetes mellitus. Elsevier, Amsterdam, pp 86-90

53. Toyota T, Ishizuka J, Ono T, Sasaki M, Shimosegawa T, Goto $Y$ (1985) Inhibitory effect of rimorphin on insulin secretion and alpha-adrenergic receptor. Diabetes 34 [Suppl 1]: 165 A

54. Ipp E, Schusdiarra V, Harris V, Unger RH (1980) Morphine-induced hyperglycaemia: role of insulin and glucagon. Endocrinology 107: 461-463
55. Ipp E, Dhorajiala J, Pugh W, Poossa AR, Rubenstain AH (1982) Effects of an enkephalin analog on pancreatic endocrine function and glucose homeostasis in normal and diabetic dogs. Endocrinology 111: 2110-2116

56. Hart IC, Cowie AT (1978) Effect of morphine, naloxone and an enkephalin analogue on plasma prolactin, growth hormone, insulin and thyroxine in goats. J Endocrinol 77: 16-17

57. Schleicher RL, Chawla RK, Coan PA, Martino-Saltzman D, Collins DC (1987) $\beta$-endorphin-induced hyperglicaemia in rabbits: effects of a glucose or arginine challenge. Am J Physiol 252: E255-E259

58. Iversen $\mathbf{J}$ (1973) Adrenergic receptors and the secretion of glucagon and insulin from the isolated, perfused canine pancreas. J Clin Invest 52: 2102-2116

59. Giugliano D (1984) Morphine, opioid peptides, and pancreatic islet function. Diabetes Care 7: 92-98

60. Lala A, Bouloux P, Tamburrano G, Gale E (1987) Opioid peptides and glucose metabolism. J Endocrinol Invest 10: 95-104

61. Schusdziarra V, Specht J, Schick R, De la Fuente A, Holland A Pfeiffer EF (1983) Effect of morphine, Leu-enkephalin and $\beta$-casomorphine on basal somatostatin release in dogs. Horm Metabol Res 15: 407-410

62. Schusdziarra V, Schick A, De la Fuente A, Specht J, Klier M, Brantl V, Pfeiffer EV (1983) Effect of $\beta$-casomorphins and analogs on insulin release in dogs. Endocrinology 112: 885889

63. Taborsky GJ Jr, Halter JB, Porte D Jr (1982) Morphine suppresses plasma catecholamine responses to laparatomy but not to 2-deoxyglucose. Am J Physiol 242: E317-E322.

64. Giugliano D, Cozzolino D, Salvatore T, Ceriello A, Torella R (1987) Dual effect of Beta-endorphin on insulin secretion in man. Horm Metabol Res 19: 502-503

65. Rossier J, French ED, Rivier C, Ling N, Guillemin R, Bloom $\mathrm{FE}$ (1977) Foot-shock induced stress increases $\beta$-endorphin levels in blood butnot in brain. Nature 270: 618-620

66. Dubois M, Pickar D, Cohen MR, Roth YF, MacNamara T, Bynney WE Jr (1981) Surgical stress in humans is accompanied by an increase in plasma $\beta$-endorphin immunoreactivity. Life Sci 29: $1249-1254$

67. Halter JB, Beard JC, Porte D Jr (1984) Islet function and stress hyperglycaemia: plasma glucose and epinephrine interaction. Am J Physiol 247: E47-E 52

68. Caldara R, Testori GP, Ferrari C, et al. (1981) Effect of loperamide, a peripheral opiate agonist, on circulating glucose, free fatty acids, insulin, C-peptide and pituitary hormones in healthy man. Eur J Clin Pharmacol 21: 185-188

69. Jeanrenaud X, Maeder E, Del Pozo E, Felber JP (1983) Effect of an enkephalin analogue (FK 33-824) on glucose tolerance in man. Acta Endocrinol (Copenh) 104: 85-90

70. Giugliano D, Ceriello A, Di Pinto P, Saccomanno F, Gentile S, Cacciapuoti $F$ (1982) Impaired insulin secretion in human diabetes mellitus. The effect of naloxone-induced opiate receptor blockade. Diabetes 31 : 367-370

71. Morley JE (1981) The endocrinology of the opiates and opioid peptides. Metabolism 30: 195-208

72. Reid LD (1985) Endogenous opioid peptides and regulation of drinking and feeding. Am J Clin Nutr 42: 1099-1132

73. Maickel RP, Braude MC, Zabik JE (1977) The effects of various narcotic agonists and antagonists on deprivation-induced fluid consumption. Neuropharmacol 16: 863-866

74. Recant L, Voyles NR, Luciano M, Pert CB (1980) Naltrexone reduces weight gain, alters " $\beta$-endorphin", and reduces insulin output from pancreatic islets of genetically obese mice. Peptides 1: 309-313

75. Margules DL, Moisset B, Lewis MJ, Shibuya H, Pert CB (1978) $\beta$-endorphin is associated with overeating in genetically obese mice (ob/ob) and rats (fa/fa). Science 202: 988 991

76. Ferguson-Segall M, Flynn JJ, Waiker J, Margules DL (1982) Increased immunoreactive dynorphin and leuenkephalin in posterior pituitary of obese mice $(\mathrm{ob} / \mathrm{ob})$ and super-sensitivity to drugs that act at kappa receptor. Life Sci 31: 2233-2236

77. Gunion MW, Peters RH (1981) Pituitary $\beta$-endorphin, nalox- 
one, and feeding in several experimental obesities. Am J Physiol 241: R173-R184

78. Morley JE, Levine AS (1982) The role of the endogenous opiates as regulators of appetite. Am J Clin Nutr 35: 757-761

79. Grandison S, Guidotti A (1977) Stimulation of food intake by muscimol and beta endorphin. Neuropharmacology 16: 533-536

80. Davis JM, Lowy MT, Yim GKW, Lamb DR, Malven PV (1983) Relationship between plasma concentrations of immunoreactive beta-endorphin and food intake in rats. Peptides 4: 79-83

81. Rossier J, Rogers J, Shibasaki T, Guillemin R, Bloom FE (1979) Opioid peptides and $\alpha$-melanocyte-stimulating hormone in genetically obese (ob/ob) mice during development. Proc Natl Acad Sci USA 76: 2077-2080

82. Morley JE (1980) The neuroendocrine control of appetite; the role of the endogenous opiates, colecystokinin, TRH, gammaaminobutyric acid and the diazepam receptors. Life Sci 27 : 355-368

83. Givens SJR, Wiedemann E, Andersen RN, Kitabchi AE (1980) $\beta$-endorphin and $\beta$-lipotropin plasma levels in hirsute women: correlation with body weight. J Clin Endocrinol Metab 50: 975-977

84. Facchinetti F, Giovannini C, Barletta C, Petraglia F, Buzzetti R, Burla F, Lazzari R, Genazzani AR, Scavo D (1986) Hyperendorphinemia in obesity and relationship to affective state. Physiol Behav 36: 937-940

85. Genazzani AR, Facchinetti F, Petraglia F, Pintor C, Corda R (1986) Hyperendorphinemia in obese children and adolescents. J Clin Endocrinol Metab 62: 36-40

86. Facchinetti F, Livieri C, Petraglia F, Cortona L, Severi F, Genazzani AR (1987) Dexamethasone fails to suppress hyperendorphinemia of obese children. Acta Endocrinol (Copenh) 116: 90-94

87. Matsumura N, Fukuda N, Saito S, Mori M (1982) Effect of a test meal, duodenal acidification and tetragastrin on the plasma concentration of B-Endorphin like immunoreactivity in man. Regul Pept 4: 173-181

88. Getto CJ, Fullerton DT, Carlson IH (1984) Plasma immunoreactive B-Endorphin response to glucose ingestion in human obesity. Appetite 5: 329-334

89. Scavo D, Facchinetti F, Barletta C, Petraglia F, Buzzetti R, Monaco M, Giovannini C, Genazzani AR (1987) Plasma betaendorphin response to oral glucose tolerance test in obese patients. Horm Metab Res 19: 204-207

90. Atkinson RL (1982) Naloxone decreases food intake in obese humans. J Clin Endocrinol Metab 55: 196-198

91. Kyriakides M, Silverstone T, Jeffcoate W, Laurance B (1980) Effect of naloxone on hyperphagia in Prader-Willi syndrome. Lancet I: 876-877

92. Thompson DA, Welle SL, Lilavivat U, Penicaud L, Campbell RG (1982) Opiate receptor blockade in man reduces 2-deoxy-dglucose-induced food intake but not hunger, thirst and hypothermia. Life Sci 31: 847-852

93. Sternbach HA, Annitto W, Pottash ALC, Gold MS (1982) Anorexic effects of naltrexone in man. Lancet I: 388-389

94. Vettor R, Martini C, Manno M, Cestaro S, Federspil G, Sicolo N (1985) Effects of naloxone-induced opiate receptors blockade on insulin secretion in obesity. Horm Metab Res 17:374-375

95. Giugliano D, Salvatore T, Cozzolino D, Ceriello A, Torella R, D'Onofrio $\mathrm{F}$ (1987) Sensitivity to $\beta$-endorphin as a cause of human obesity. Metabolism 36: 974-978

96. Givens JM, Kurtz BR, Kitabchi AE, Tittle JB, Karas JG, Mirchell JA, Howes JF (1987) Reduction of hyperinsulinemia and insulin resistance by opiate receptor blockade in the polycystic ovary syndrome with acanthosis nigricans. J Clin Endocrinol Metab 64: 377-382

97. Giugliano D, Salvatore T, Cozzolino D, Torella R, D'Onofrio F (1987) Hyperglycaemia and obesity as determinants of glucose, insulin, and glucagon responses to $\beta$-endorphin in human diabetes mellitus. J Clin Endocrinol Metab 64: 1122-1128

98. Jung RT, Campbell RG, James WPT, Callingham BA (1982)
Altered hypothalamic and sympathetic responses to hypoglycaemia in familial obesity. Lancet I: 1043-1046

99. Leslie RDG, Pyke DA, Stubbs WA (1979) Sensitivity to enkephalin as a cause on non-insulin-dependent diabetes. Lancet I: 341-343

100. Leslie RDG, Barnett AH, Pyke DA (1979) Chlorpropamide alcohol flushing and diabetic retinopathy. Lancet I: 997-999

101. Wiles PG, Hoskins P, Leslie RDG, Pyke DA (1984) Prevalence of chlorpropamide alcohol flushing (Letter). Br Med J 288: 328

102. Wiles PG, Pyke DA (1984) The chlorpropamide alcohol flush. Clinical Science 67: 375-381

103. Greenberg J, Ellyin F, Pullen G, Ehrenpreis S, Singh AP, Cheng $\mathrm{J}$ (1985) Methionine-enkephalin and $\beta$-endorphin levels in brain, pancreas, and adrenals of $\mathrm{db} / \mathrm{db}$ mice. Endocrinology 116: 328-331

104. Timmers K, Voyles NR, Zalenski C, Wilkins S, Recant L (1986) Altered $\beta$-endorphin, Met- and Leu-enkephalins, and enkephalin-containing peptides in pancreas and pituitary of genetically obese diabetic $(\mathrm{db} / \mathrm{db})$ mice during development of diabetic syndrome. Diabetes 35: 1143-1151

105. Forman LJ, Marquis DE, Stevens $R$, Adler R, Vasilenko $P$ (1985) Diabetes induced by streptozotocin results in a decrease in immunoreactive beta-endorphin levels in the pituitary and hypothalamus of female rats. Diabetes 34: 1104-1107

106. Awoke S, Voyles NR, Bathena SJ, Tanenberg RJ, Recant L (1984) Alterations of plasma opioid activity in human diabetics. Life Sci 34: 1999-2006

107. Vermes I, Steinmetz E, Schoorl J, Van der Veen EA, Tilders FJH (1985) Increased plasma levels of immunoreactive $\beta$-endorphin and corticotropin in non-insulin-dependent diabetes (Letter). Lancet II: 725-726

108. Burrin JM, Yeo TH, Kohner EM, Jones J (1986) Plasma immunoreactive $\beta$-endorphin in non-insulin-dependent diabetes (Letter). Lancet I: 855

109. Solerte SB, Petraglia F, Facchinetti F, Genazzani AR, Ferrari E (1985) Dissociation between $\beta$-lipotropin and ACTH secretion in type-1 and type-2 diabetes mellitus. J Endocrinol Invest 8 [Suppl 3]: 197A

110. Reid RL, Sandler JA, Yen SSC (1984) Beta-endorphin stimulates the secretion of insulin and glucagon in diabetes mellitus. Metabolism 33: 197-199

111. Giugliano D, Ceriello A, Salvatore T, Paolisso G, D'Onofrio F, Lefebvre PJ (1987) $\beta$-endorphin infusion restores acute insulin responses to glucose in type- 2 diabetes mellitus. J Clin Endocrinol Metab 64: 944-948

112. Giugliano $\mathrm{D}$, Ceriello $\mathrm{A}$, Quatraro A, D'Onofrio $\mathrm{F}$ (1987) $\beta$-endorphin and the secretion of islet hormones in NIDDM. Diabetes [Suppl 1] 36: 123A

113. Giugliano D, Cozzolino D, Salvatore T, Ceriello A, Giunta R, Torella R, D'Onofrio F (1988) $\beta$-endorphin and islet hormone release in type-2 diabetes mellitus. The effect of normoglycaemia, enkephalin, naloxone and somatostatin. Diabete Metab (in press)

114. Levine AS, Morley JE, Brown DM, Handwerger BS (1982) Extreme sensitivity of diabetic mice to naloxone-induced suppression of food intake. Physiol Behav 28: 987-989

115. Giugliano D, Di Pinto P, Ceriello A, Saccomanno F, Passariello N, D'Onofrio F (1985) Impaired insulin secretion in human diabetes mellitus. Interactions between naloxone, phentolamine and lysine acetylsalicylate upon glucose-induced release. Diabete Metab 11: 350-358

116. Verlohren HJ, Jahr J (1984) Insulin secretion in type-II diabetes. In vivo and in vitro investigations. Exp Clin Endocrinol 83: 216-224

117. Passariello N, Giugliano D, Ceriello A, Chiariello A, Sgambato S, D'Onofrio F (1986) Impaired insulin response to glucose but not to arginine in heroin addicts. $J$ Endocrinol Invest 9: 953-957

118. Passariello N, Giugliano D, Quatraro A, Consoli G, Sgambato S, Torella R, D'Onofrio F (1983) Glucose tolerance and hormonal responses in heroin addicts. A possible role for endoge- 
nous opiates in the pathogenesis of non-insulin-dependent diabetes. Metabolism 32: 1163-1165

119. Giugliano D, Ceriello A, Quatraro A, D'Onofrio F (1985) Endogenous opiates, heroin addiction and non-insulin-dependent diabetes. Lancet II: 769-770

120. Giugliano D (1985) Secrezione insulinica nel diabete non insulino-dipendente. Gior Ital Diabetol 5: 347-357

121. Ceriello A, Giugliano D, Dello Russo P, Sgambato S, D'Onofrio $F$ (1982) Increased glycosylated haemoglobin $A_{1}$ in opiate addicts: evidence for hyperglycaemic effect of morphine. Diabetologia 22: 379 (Letter)

122. Ceriello A, Dello Russo P, Curcio F, Rossano P (1984) Increased glycosylated proteins in opiate addicts. Diabetes Care 7: 104-105

123. Ceriello A, Dello Russo P, Niola O, Capezzuto C, Schimizzi S (1983) Fibrinogen levels in opiate addicts. Thromb Haemostas 50: 755 (Letter)

124. Ceriello A, Dello Russo P, Curcio F, Giugliano D (1985) Mean red cell volume, narcotic addiction and glucose tolerance. Arch Intern Med 145: 1530 (Letter)

125. Ceriello A, Dello Russo P, Curcio F, Petringa D, D'Ippolito S, Varriale M (1983) Morphine, diabetes and lipid metabolism. Arch Intern Med 143: 1070 (Letter)

126. Ceriello A, Dello Russo P, Curcio F, Tirelli A, Giugliano D (1984) Depressed antithrombin III biological activity in opiate addicts. J Clin Pathol 37: 1040-1042

127. Ceriello A, Dello Russo P, Zuccotti C, Florio A, Nazzaro S, Pietrantuono C, Rosato GB (1983) Decreased antithrombin III activity in diabetes may be due to non-enzymatic glycosylation. A preliminary report. Thromb Haemostas 50: 633-634
128. Giugliano D, Quatraro A, Consoli G, Stante A, Simeone V, Ceriello A, Paolisso G, Torella R (1987) Sodium salicylate restores the impaired insulin response to glucose and improves glucose tolerance in heroin addicts. Acta Diabetol Lat 24: 205-212

129. Gerich J, Karam J, Forsham P (1973) Stimulation of glucagon secretion by epinephrine in man. J Clin Endocrinol Metab 37: 479-480

130. Clutter WE, Bier DM, Shah SD, Cryer PE (1980) Epinephrine plasma metabolic clearance rates and physiologic thresholds for metabolic and hemodynamic actions in man. J Clin Invest 66: 94-101

131. Giugliano D, Ceriello A, Quatraro A, Paolisso G, Varano R, D'Onofrio F (1985) Interaction between epinephrine, prostaglandin $\mathrm{E}$ and Met-enkephalin in the regulation of insulin release in man. Diabete Metab 11: 295-302

132. Jeanrenaud B (1985) An hypothesis on the etiology of obesity: disfunction of the central nervous system as a primary cause. Diabetologia 28: 502-513

133. Giugliano D, Ceriello A, Torella R, D'Onofrio F (1986) Opiacés et diabète non-insulino-dépendant. Journ Annu Diabétol Hôtel Dieu, pp 185-197

Received: 9 November 1987

Professor D. Giugliano

Cattedra di Diabetologia e Dietoterapia

$\mathrm{I}^{\circ}$ Policlinico Universitario

Piazza L. Miraglia

I-80138 Napoli

Italy 